\title{
Expression pattern of placenta specific 8 and keratin 20 in different types of gastrointestinal cancer
}

\author{
CHIH-SHENG HUNG ${ }^{1}$, YEN-CHIEH WANG ${ }^{2,3}$, JIUN-WEN GUO ${ }^{4,5}$, RUEY-NENG YANG ${ }^{6,7}$, CHIA-LONG LEE ${ }^{1,3}$, \\ MING-HUNG SHEN ${ }^{3,8,9}$, CHI-CHENG HUANG ${ }^{10}$, CHI-JUNG HUANG ${ }^{3-5,11}$, JHIH-YUN YANG ${ }^{12}$ and CHIH-YI LIU ${ }^{13}$ \\ ${ }^{1}$ Department of Internal Medicine, Division of Gastroenterology; \\ ${ }^{2}$ Department of Surgery, Division of Urology, Cathay General Hospital, Taipei 10630; ${ }^{3}$ School of Medicine, \\ College of Medicine, Fu Jen Catholic University, New Taipei 24205; ${ }^{4}$ Department of Medical Research, \\ Cathay General Hospital, Taipei 10630; ${ }^{5} \mathrm{PhD}$ Program in Pharmaceutical Biotechnology, College of Medicine, \\ Fu Jen Catholic University, New Taipei 24205; ${ }^{6}$ Department of Internal Medicine, Sijhih Cathay General Hospital, \\ New Taipei 22174; ${ }^{7}$ Department of Nursing, Ching Kuo Institute of Management and Health, Keelung 20301; \\ ${ }^{8}$ Department of Surgery, Fu Jen Catholic University Hospital, New Taipei 24352; ${ }^{9} \mathrm{PhD}$ Program in Nutrition \\ and Food Science, Fu Jen Catholic University, New Taipei $24205 ;{ }^{10}$ Department of Surgery, \\ Taipei-Veterans General Hospital, Taipei 11217; ${ }^{11}$ Department of Biochemistry, National Defense Medical Center, \\ Taipei 11490; ${ }^{12}$ Department of Mathematics, Taipei Wego Private Senior High School, Taipei 11254; \\ ${ }^{13}$ Department of Pathology, Sijhih Cathay General Hospital, New Taipei 22174, Taiwan, R.O.C.
}

Received February 22, 2019; Accepted November 6, 2019

DOI: $10.3892 / \mathrm{mmr} .2019 .10871$

\begin{abstract}
The aim of the present study was to investigate the expression of keratin 20 (KRT20) and placenta specific 8 (PLAC8) in gastrointestinal (GI) cancer with various differentiation phenotypes. The present study retrospectively investigated archived formalin-fixed paraffin-embedded tissue samples from 12 patients at different stages of GI cancer [four with gastric cancer, four with pancreatic cancer and four with colorectal cancer (CRC)]. The stages were pre-determined, according to differentiation phenotypes, by a pathologist of the Department of Pathology at Sijhih Cathay General Hospital. KRT20 and PLAC8 expression levels were assessed using immunohistochemistry. The CRC cell lines SW620 and Caco-2 were used to assess interactions between KRT20 and PLAC8 via reverse transcription-quantitative PCR. PLAC8 and KRT20 expression was observed consistently only in the well-differentiated CRC tissue samples. Low KRT20 expression levels were observed in the PLAC8 knockdown SW620 cells. In addition, there was a positive association between PLAC8 and KRT20 expression in the differentiated Caco- 2 cells. According to the results of the present study, the differentiation status of GI cancer influenced KRT20 expression, particularly in CRC, which may explain why
\end{abstract}

Correspondence to: Dr Chih-Yi Liu, Department of Pathology, Sijhih Cathay General Hospital, 2 Lane 59, Jiancheng Road, New Taipei 22174, Taiwan, R.O.C.

E-mail: cyl1124@gmail.com

Key words: gastrointestinal cancer, keratin 20, placenta specific 8, poorly differentiated, well differentiated patients with well-differentiated CRC display better clinical outcomes. Therefore, the prognostic significance of KRT20 and PLAC8 may be particularly crucial for patients with CRC displaying a well-differentiated phenotype.

\section{Introduction}

Gastrointestinal (GI) cancer develops in the organs of the alimentary canal, including the esophagus, liver and bile ducts, gallbladder, pancreas, stomach and small and large intestines (1). Although some distinct mutations have been reported in different GI organs, GI tumors display several key molecular alterations $(2,3)$.

Keratins (KRTs) are a family of fibrous structural proteins that are present in normal epithelia, however, some are upregulated in neoplasms (4). The differential expression of KRTs facilitates the diagnosis of several tumors, including GI tumors, using molecular techniques and allows KRTs to be used as biomarkers to discriminate primary from metastatic adenocarcinoma (5-8). In addition, KRTs have long been considered epithelial differentiation markers (9) and the differentiation of cells within the GI tract is associated with an increased susceptibility to GI cancer $(10,11)$.

In addition to being involved in conventional tumorigenesis, epithelial-mesenchymal transition (EMT) plays key roles in cellular differentiation and cancer progression $(12,13)$. KRTs have been reported to be aberrant in cells undergoing EMT $(14,15)$. For example, the detection of KRT20-positive circulating tumor cells is associated with worse prognosis in patients with colorectal cancer (CRC) (16). In addition to structural KRTs, other genes often exhibit dysregulated expression during EMT. Previously, placenta specific 8 (PLAC8), a gene expressed under physiological conditions, was reported to play 
a key role in the tumorigenic and EMT pathways in a number of types of human cancer, such as CRC or pancreatic cancer (CaP) $(17,18)$. PLAC8 was expressed at high levels in the GI tract and KRT20 expression patterns were highly specific (19-21). In addition, elevated PLAC8 levels are positively associated with tumor metastasis and recurrence in CRC $(18,22)$. Understanding the interaction between KRT20 and PLAC8 could have clinical implications for the treatment of GI cancer. In the present study, immunostaining was employed to detect the expression of KRT20 and PLAC8 in the tissues of patients with GI cancer [gastric cancer (GC), $\mathrm{CaP}$ and $\mathrm{CRC}$ ]. Furthermore, the mRNA levels of KRT20 in CRC cells displaying differential PLAC8 expression were quantified.

\section{Materials and methods}

Tissues and cell lines. Archived $4 \mu \mathrm{m}$ formalin-fixed paraffin-embedded (FFPE) tissue sections from four GC, four $\mathrm{CaP}$ and four CRC patients who had undergone surgery at the Department of Surgery of Cathay General Hospital before December, 2000 were obtained and used in the present study. All procedures were approved by the Cathay General Hospital Institutional Ethics Committee and a waiver of consent was approved by the same committee. Patient information was anonymized.

For each cancer (GC, CaP and CRC), two patients had well-differentiated cancer [one at American Joint Committee on Cancer (AJCC) stage II and one at stage III] and two had poorly differentiated cancer (one at AJCC stage II and one at stage III) (23). Cancer diagnoses were performed by a pathologist. The human CRC cell lines SW620 [cat. no. CRL-1831; AJCC stage III) and Caco-2 (cat. no. HTB-37) were obtained from the American Type Culture Collection (ATCC) and the medium suggested by the ATCC for each cell line was used for culture; Leibovitz's L-15 medium for SW620 cells and the Eagle's Minimum Essential medium for Caco-2 cells. The two CRC cell lines were selected due to their high PLAC8 expression levels (SW620 cells) (24) and their differentiation capacity (Caco-2 cells) (25). SW620 cells were incubated at $37^{\circ} \mathrm{C}$ and $100 \%$ air (with very low $\mathrm{CO}_{2}$ ) in a humidified incubator and subcultured 2 to 3 times per week (25). To induce intestinal differentiation, Caco-2 cells were cultured to confluence in a humidified incubator at $37^{\circ} \mathrm{C}$ with $5 \% \mathrm{CO}_{2}$ for 21 days, as described in a previous study (25).

PLAC8 knockdown and detection of PLAC8 mRNA level in $C R C$ cells. PLAC8 mRNA levels were knocked down in SW620 cells using a lentivirus-mediated small hairpin (sh) RNA targeting PLAC8 to obtain shPLAC8-SW620 cells. Control (shLUC-SW620) cells were obtained using a lentivirus-mediated shRNA targeting luciferase (25). The lentiviruses and the protocol for lentivirus infection were acquired from the National RNAi Core Facility of Academia Sinica. Briefly, $1 \times 10^{6} \mathrm{SW} 620$ cells were grown in a $10 \mathrm{~cm}$ plate for $24 \mathrm{~h}$, and then infected with lentivirus at a multiplicity of infection of 3. Stable infected cells were selected and maintained in medium containing $2 \mu \mathrm{g} / \mathrm{ml}$ puromycin for $48 \mathrm{~h}$ (Thermo Fisher Scientific, Inc.). The total RNA of the transfected cells was then extracted using RNAzol ${ }^{\circledR}$ RT (Molecular Research Center) and reverse transcribed into
cDNA using a high-capacity cDNA Reverse Transcription kit (Catalog No. 4368813; Thermo Fisher Scientific, Inc.) in the presence of oligo(dT) primers, according to the manufacturer's instructions. The level of mRNA was considered as the gene expression level and was measured by PCR in the presence of specific amplification primers (Table I), a TaqMan probe and TaqMan master mix (Roche Diagnostics GmbH), according to the manufacturer's instructions. Cycling conditions were: $2 \mathrm{~min}$ at $50^{\circ} \mathrm{C}$ and $10 \mathrm{~min}$ at $95^{\circ} \mathrm{C}$, followed by 50 cycles each consisting of $15 \mathrm{sec}$ at $95^{\circ} \mathrm{C}$ and $1 \mathrm{~min}$ at $60^{\circ} \mathrm{C}$. mRNA levels were adjusted relative to the level of GAPDH to estimate the relative levels of gene expression with the method of the $2^{-\Delta \Delta \mathrm{Cq}}$ method (26). LightCycler (version 4.05; Roche Diagnostics $\mathrm{GmbH})$ was used to analyze the PCR kinetics.

Immunohistochemical staining of PLAC8 and KRT20 in the archived FFPE tissue sections. For the PLAC8 immunohistochemical staining, a VECTASTAIN ${ }^{\circledR}$ Elite ABC kit (Vector Laboratories, Inc.) was used according to the manufacturer's instructions. Briefly, cancer tissue sections were incubated in oven at $65^{\circ} \mathrm{C}$ for $30 \mathrm{~min}$ to deparaffinize, and then each tissue was rehydrated with 100,90 and $70 \%$ ethanol, sequentially. The rehydrated slides were immersed in citrate buffer $(10 \mathrm{mM}$; $\mathrm{pH} 6.0)$, boiled $\left(95-99^{\circ} \mathrm{C}\right.$ ) for $20 \mathrm{~min}$ and then cooled to room temperature for $20 \mathrm{~min}$. To inactivate endogenous peroxidases within the tissues, the slides were incubated for $30 \mathrm{~min}$ at room temperature in $3 \%$ methanolic hydrogen peroxide. The tissue sections were then blocked for $30 \mathrm{~min}$ at room temperature using a blocking solution with 5\% rabbit serum (Vector Laboratories, Inc.) and incubated overnight at $4^{\circ} \mathrm{C}$ with anti-PLAC8 antibody (1:200; cat. no. ab122652; Abcam) or anti-KRT20 antibody (1:200; cat. no. ab76126; Abcam). After washing the tissues several times with Tris-buffered saline, the samples were incubated with a secondary biotinylated goat anti-rabbit IgG antibody (1:200; cat. no. BA-1000; Vector Laboratories) for $1 \mathrm{~h}$ at room temperature. Subsequently, the slides were stained with 3-amino-9-ethylcarbazole (DAKO; Agilent Technologies, Inc.) for $1 \mathrm{~min}$ at room temperature to visualize PLAC8 and KRT20. Tissues were stained with hematoxylin for $4 \mathrm{~min}$ and then with eosin for another $1.5 \mathrm{~min}$ at room temperature for identification of normal and tumor areas. The stained sections were subsequently diagnosed by a pathologist via a light microscope Olympus BX41 with magnification at x200 (Olympus Corp.). Then, the GI cancer tissue sections were divided into two differentiation states (well or moderately differentiated, $>50 \%$ glandular formation and poorly differentiated, 0-49\% glandular formation) (27).

Statistical analysis. Data were presented as mean \pm standard deviation. The relative expression levels of PLAC8 and KRT20 in cells were compared between samples using the Student's t-test. All statistical analyses were performed using SPSS (version 19; IBM Corp.). $\mathrm{P}<0.05$ was considered to indicate a statistically significant difference.

\section{Results}

PLAC8 and KRT20 expression in well-differentiated GI stage II and III cancer cells. Cellular KRT20 and PLAC8 proteins were detected in each of the cancer tissues using immunohistochemistry. In the well-differentiated 
Table I. Quantitative PCR primers.

Primers $\left(5^{\prime} \rightarrow 3^{\prime}\right)$

\begin{tabular}{lll}
\cline { 2 - 3 } Gene & \multicolumn{1}{c}{ Forward } & \multicolumn{1}{c}{ Reverse } \\
\hline PLAC8 & CGTCGCAATGAGGACTCTCT & CTCTTGATTTGGCAAAGAGTACAA \\
KRT20 & CAGTCCCATCTCAGCATGAA & ACAGCGACTGGAGGTTGG \\
GAPDH & CTCTGCTCCTCCTGTTCGAC & ACGACCAAATCCGTTGACTC \\
\hline
\end{tabular}

PLAC8, placenta specific 8; KRT20, keratin 20.

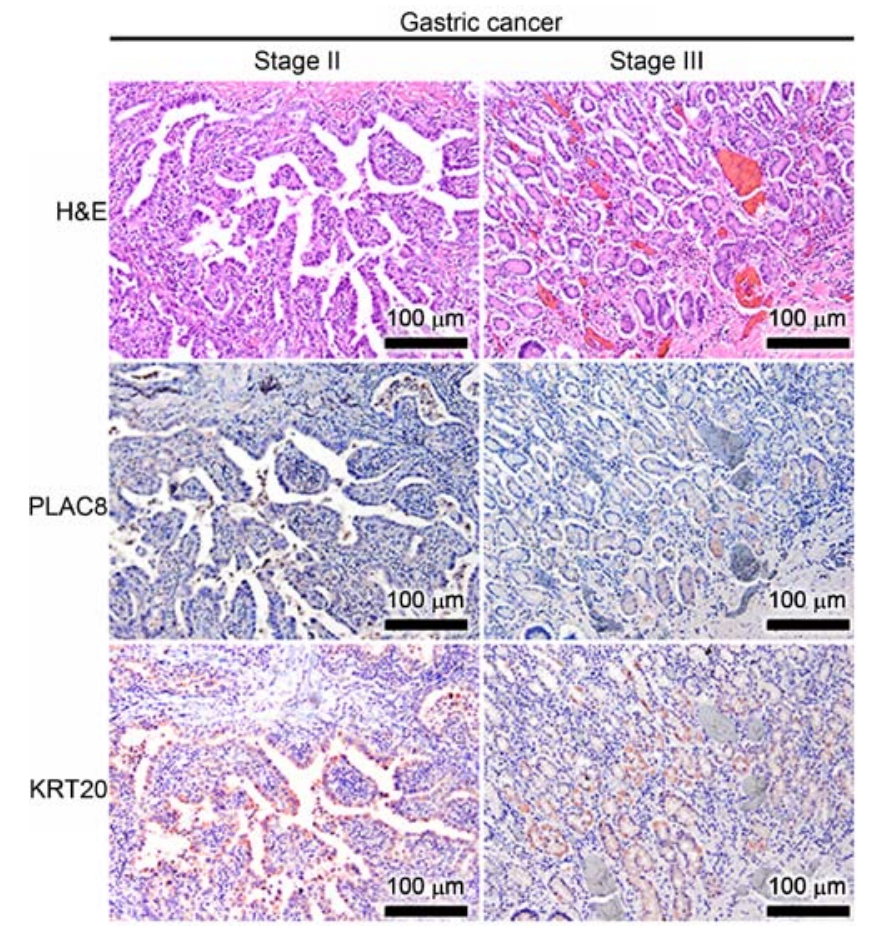

Figure 1. Representative immunohistochemical staining for PLAC8 and KRT20 expression in well differentiated stage II and III gastric cancer tissue. Scale bar displayed in bottom right corner, magnification, x200. H\&E, hematoxylin and eosin staining; PLAC8, placenta specific 8; KRT20, keratin 20.

GC cancer tissues, PLAC8 levels were low and tissues were KRT20-positive regardless of tumor stage (Fig. 1). Conversely, tissues were positive for both PLAC8 and KRT20 in the well-differentiated CaP tissues at stages II and III, but PLAC8 displayed a luminal staining pattern (Fig. 2). In addition to the expression patterns in the well-differentiated $\mathrm{GC}$ and $\mathrm{CaP}$ cases, the expression patterns of PLAC8 and KRT20 were also immunodetected in well-differentiated CRC cases (Fig. 3). PLAC8 signals were consistently low in the well-differentiated CRC at stage II (the left panel of Fig. 3), but the small number of PLAC8-positive CRC cells appeared to also express KRT20. Furthermore, a co-expression of PLAC8 and KRT20 was observed in the well-differentiated CRC cells at stage III (the right panel of Fig. 3).

PLAC8 and KRT20 expression in the poorly differentiated GI cancer cells at stages II and III. Immunohistochemical

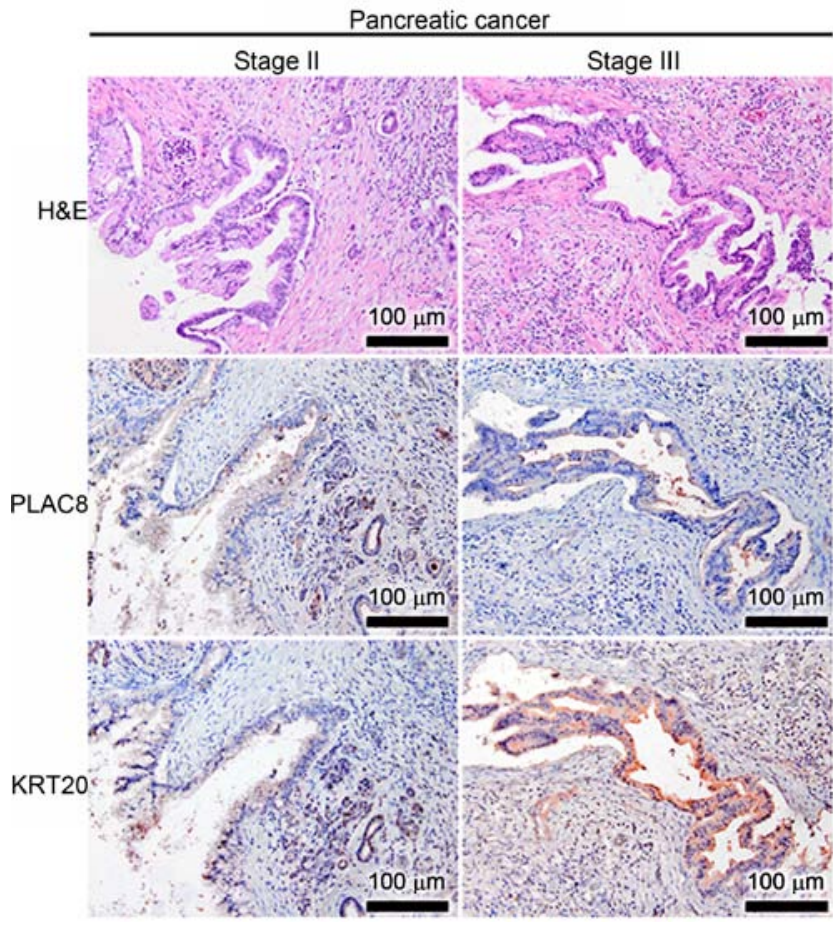

Figure 2. Representative immunohistochemical staining for PLAC8 and KRT20 expression in well differentiated stage II and III pancreatic cancer tissue. Scale bar displayed in bottom right corner, magnification, x200. H\&E, hematoxylin and eosin staining; PLAC8, placenta specific 8; KRT20, keratin 20.

staining revealed that although poorly differentiated GC tissues expressed similar levels of PLAC8 at stage II and III (the middle panel of Fig. 4), these tissues expressed higher levels of KRT20 at stage III compared to stage II (the bottom panel of Fig. 4). Conversely, the poorly differentiated $\mathrm{CaP}$ at stage II displayed higher levels of PLAC8 compared with the CaP tissues at stage III, and KRT20 levels were low in the poorly differentiated $\mathrm{CaP}$ at both stage II and III (Fig. 5). The PLAC8 and KRT20 expression patterns in poorly differentiated CRC were different from those in well-differentiated CRC (Fig. 6). PLAC8 expression was higher in the poorly differentiated CRC tissue at stage III than at stage II (the middle panel of Fig. 6). However, the late tumor stage (stage III) did not appear to increase the expression of KRT20 in the poorly differentiated CRC tissue.

PLAC8 and KRT20 expression levels in transfected and differentiated $C R C$ cell lines. PLAC8 expression was knocked 


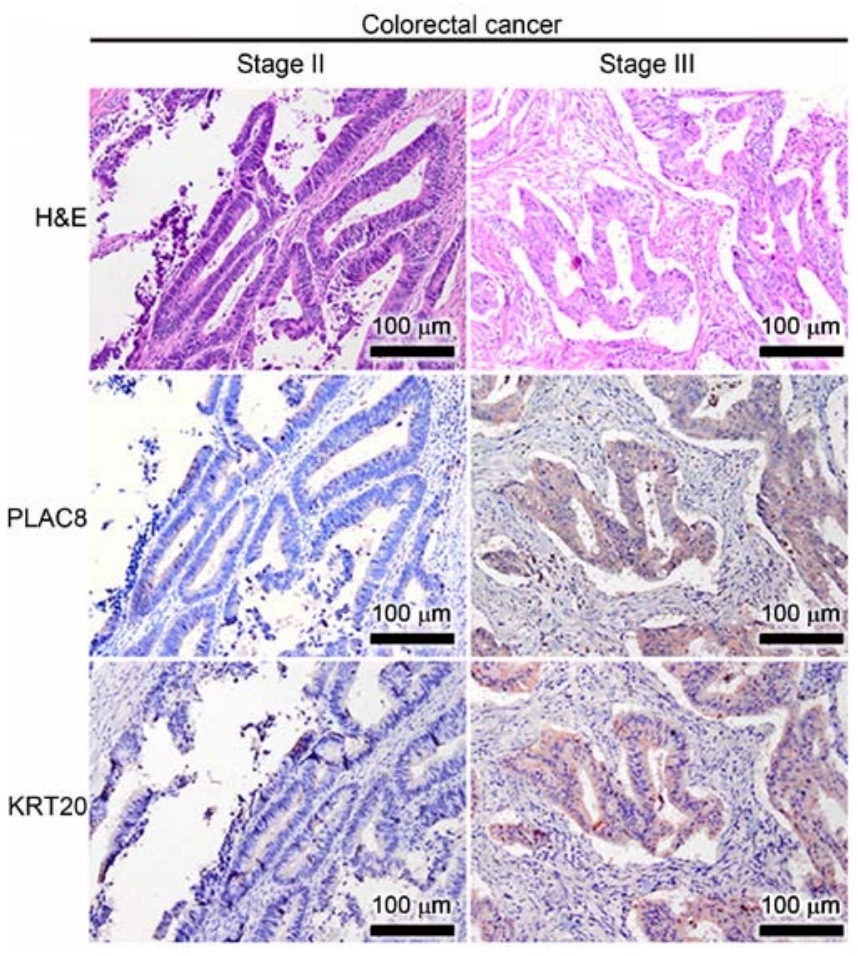

Figure 3. Representative immunohistochemical staining for PLAC8 and KRT20 expression in well differentiated stage II and III colorectal cancer tissue. Scale bar displayed in bottom right corner, magnification, x200. H\&E, hematoxylin and eosin staining; PLAC8, placenta specific 8; KRT20, keratin 20.

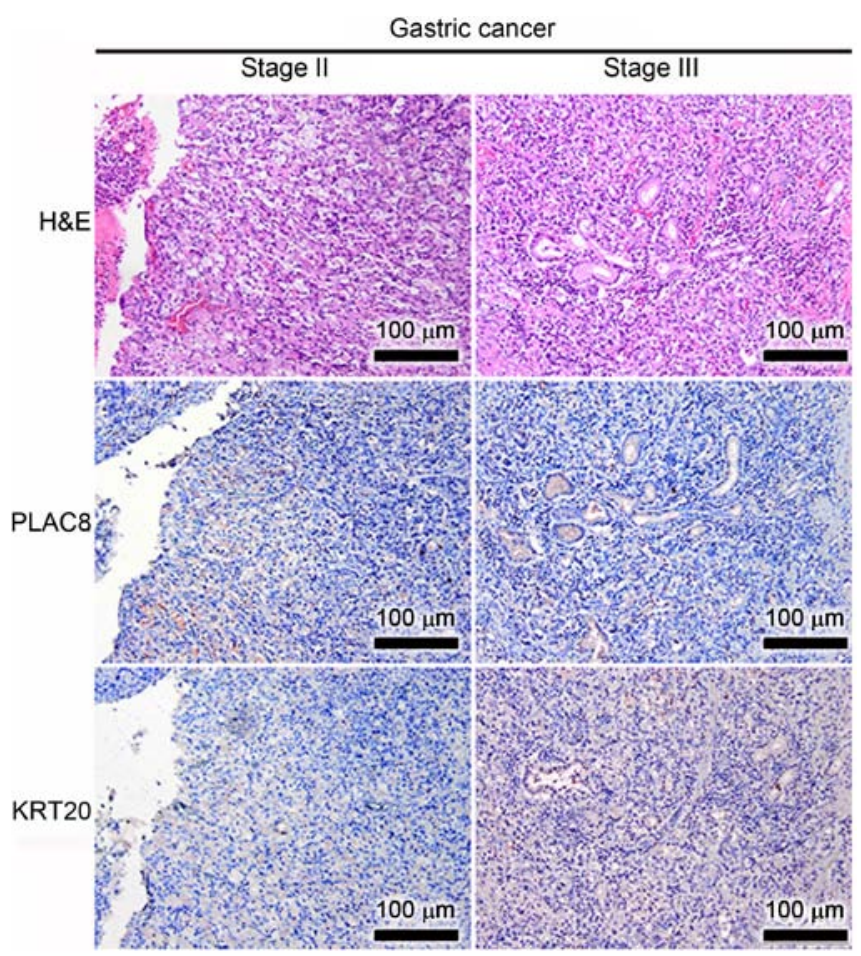

Figure 4. Representative immunohistochemical staining for PLAC8 and KRT20 expression in poorly differentiated stage II and III gastric cancer tissue. Scale bar displayed in bottom right corner, magnification, x200. H\&E, hematoxylin and eosin staining; PLAC8, placenta specific 8; KRT20, keratin 20.

down in SW620 cells, displayed by an $80 \%$ decrease in PLAC8 mRNA levels (shPLAC8-SW620) compared with the levels in

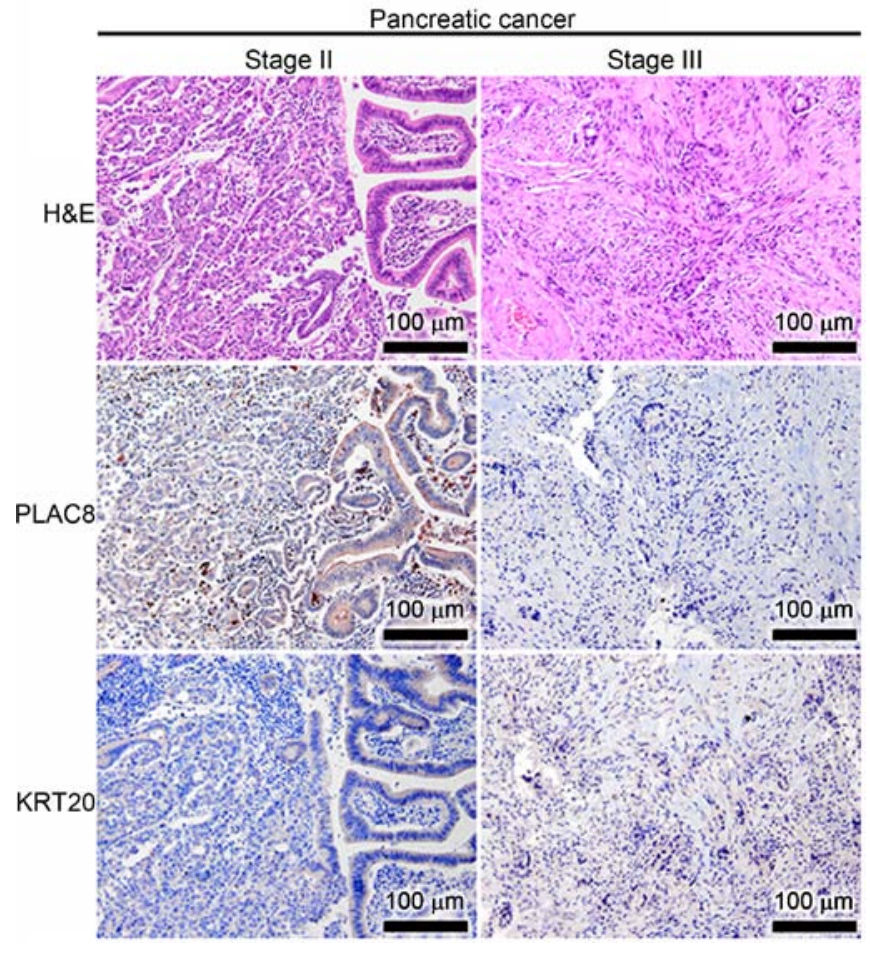

Figure 5. Representative immunohistochemical staining for PLAC8 and KRT20 expression in poorly differentiated stage II and III pancreatic cancer tissue. Scale bar displayed in bottom right corner, magnification, x200. H\&E, hematoxylin and eosin staining; PLAC8, placenta specific 8; KRT20, keratin 20.

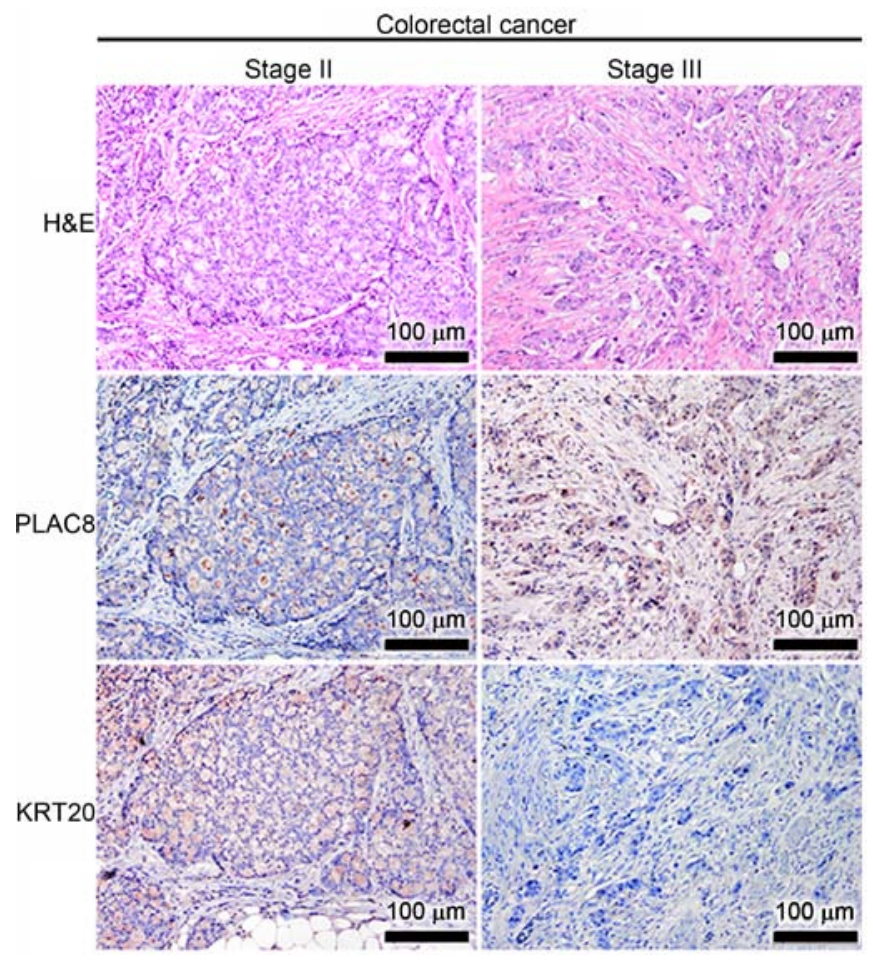

Figure 6. Representative immunohistochemical staining for PLAC8 and KRT20 expression in poorly differentiated stage II and III colorectal cancer tissue. Scale bar displayed in bottom right corner, magnification, x200. H\&E, hematoxylin and eosin staining; PLAC8, placenta specific 8; KRT20, keratin 20.

the control cells (shLUC-SW620; Fig. 7A). The KRT20 mRNA levels in the shPLAC8-SW620 cells also decreased by $76 \%$ 

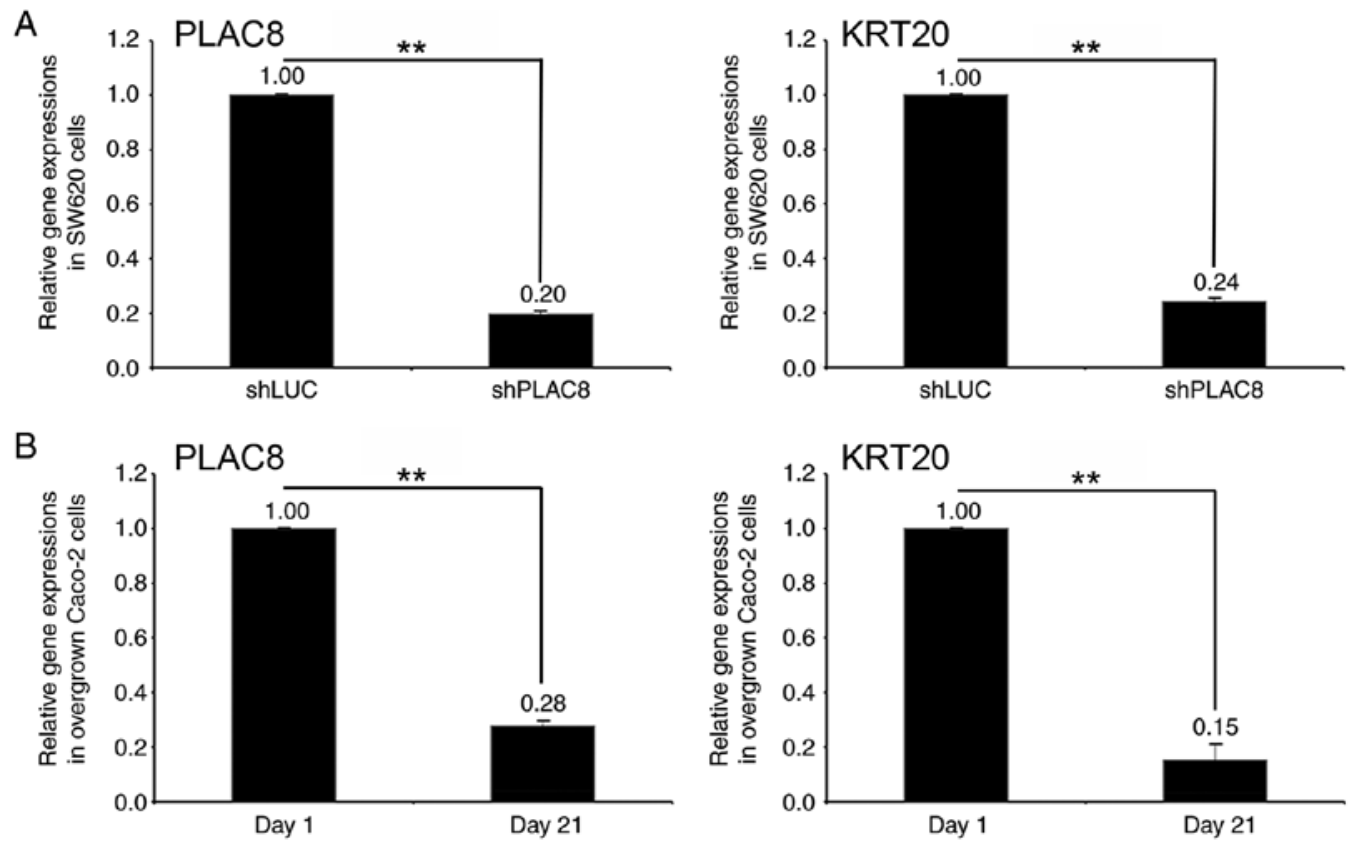

Figure 7. Expression patterns of PLAC8 and KRT20 in CRC cell lines. (A) Relative gene expression of PLAC8 and KRT20 in transfected SW620 cells. SW620 cells were cultured in a humidified and $\mathrm{CO}_{2}$-free incubator. (B) Relative gene expression of PLAC 8 and KRT20 in Caco-2 cells. Caco-2 cells were differentiated in a humidified incubator with $5 \% \mathrm{CO}_{2}$ for 21 days. Data were presented as mean \pm standard deviation and compared between samples using the Student's $t$-test, ${ }^{* *} \mathrm{P}<0.01$. PLAC8, placenta specific 8; KRT20, keratin 20. CRC, colorectal cancer; sh, short hairpin.

compared with the levels in the control cells (Fig. 7A). The mRNA levels of both PLAC8 and KRT20 in the differentiated Caco-2 cells (day 21) decreased by 72 and $85 \%$, respectively, compared with the levels in the day $1 \mathrm{Caco}-2$ cells (Fig. 7B).

\section{Discussion}

In clinical settings, patients with different types of GI cancer should be diagnosed using appropriate biomarkers, even though gut-derived adenocarcinomas display similar genetic alterations (28-32). Lukyanchuk et al (33) reported that KRT20 had clinical significance in GI cancer, including $\mathrm{GC}, \mathrm{CaP}$ and CRC. Thus, the present study focused on investigating KRT20 and PLAC8 expression in these types of GI cancer. In the present study, the aberrant co-expression of the cytoplasmic protein PLAC8 and the cytokeratin KRT20 were found in the well-differentiated CRC at stage III, but this expression pattern was not observed in poorly differentiated CRC. No such co-expression was observed in the GC and $\mathrm{CaP}$ tissue sections, regardless of tumor stage and differentiation state. CRC tissues at stages II and III have been frequently studied to improve prognosis and to avoid the incorrect use of chemotherapeutic agents $(34,35)$.

Cytoskeletal rearrangement is required for cell migration and invasion, which are key steps in cancer metastasis $(36,37)$. Highly dynamic biological processes of cytoskeletal organization in cancer have been extensively explored (38-42). Among the different cytoskeletal molecules, KRTs might be the most examined based on clinical significance $(43,44)$, and several KRTs have been previously studied from a tumor progression perspective (45-47). For example, previous studies have reported that upregulation of KRT17 and KRT19 may be involved in tumor metastasis $(5,48)$ and that KRT18 and
KRT19 are associated with colorectal malignancy (49-52). In addition, aberrant KRT20 expression has been observed in generalized GI cancer $(16,19,53)$ and is recognized as a marker of circulating CRC cells (54). Therefore, KRT20 could be a suitable marker for the evaluation of the primary origin of GI cancer, including CRC $(19,55)$.

PLAC8, a novel oncogenic marker that mediates tumor progression, has also been reported to play a key role in the EMT of CRC $(18,22)$. In the present study, an association between KRT20 and PLAC8 expression was observed in CRC cells. The KRT20 mRNA levels decreased in the PLAC8-knockdown SW620 CRC cells, which were diagnosed as AJCC stage III. In addition, the intestinal differentiation of Caco-2 cells was used to evaluate the well-differentiated state of GI cancer $(56,57)$. Such spontaneously differentiated Caco-2 cells displayed decreasing levels of KRT20 and PLAC8 expression upon differentiation. The Caco-2 cell line, which is applied extensively as an intestinal epithelial barrier model, displays favorable differentiation in a continuous culture $(58,59)$. In addition, the positive association between KRT20 and PLAC8 expression levels in the well-differentiated CRC was confirmed by immunostaining of archived FFPE tissue sections. The FFPE tissue sections of other well-differentiated GI cancer ( $\mathrm{GC}$ and $\mathrm{CaP}$ ) at stages II and III did not display patterns similar to those of CRC and no association between PLAC8 and KRT20 expression levels were observed in the three poorly differentiated GI cancer tissues (GC, $\mathrm{CaP}$ and $\mathrm{CRC}$ ). The results from the present study suggested that understanding the expression of PLAC8 and KRT20 could be critical for predicting the prognosis of patients with CRC.

Experiments exploring the molecular heterogeneity of CRC could facilitate the formulation of effective therapies $(60,61)$. 
CRC development and progression is a complex process involving multiple genetic changes (62-64). The genes involved in CRC tumorigenesis should therefore be identified for clinical applications (65). Chemotherapy, target molecule therapy (with vascular endothelial growth factor or epidermal growth factor receptor) and immunotherapy (anti-programmed death-1) lead to increased survival rates and decreased recurrence rates in CRC (66-68). Imai et al (69) revealed that the KRT20 expression was closely associated with the invasive histological phenotype in poorly differentiated colorectal adenocarcinoma. However, in the present study, it was suggested that the differentiation status of GI cancer may influence KRT20 expression, particularly in CRC.

A recent animal study reported that PLAC8 expression might be associated with the gut microbiota (70) and others detected that aberrant KRT20 expression is induced by altering the gut microbiota (71). Taken together, these results implied that KRT20 and PLAC8 might work cooperatively in different types of GI cancer. The present study suggested that PLAC8 expression could influence KRT20 expression. Therefore, it could be hypothesized that a well-differentiated CRC may have poor prognosis if KRT20 is induced via the upregulation of PLAC8. Conversely, the downregulation of PLAC8 may reduce the expression levels of KRT20. These suggested molecular dynamics imply that RNA interference of PLAC8 expression could be used as a therapeutic technique for the treatment of GI cancer at stages II and III. A similar concept that uses small interfering RNA as a cancer therapeutic agent has been explored extensively (72-74). In addition, PLAC 8 promotes tumor growth, invasion and metastasis in other tumors, which could explain why patients with well-differentiated CRC display different clinical outcomes, in comparison with the patients with poorly-differentiated CRC $(17,22,75,76)$. Therefore, the prognostic significance of KRT20 and PLAC8 could be particularly essential for patients with CRC displaying well-differentiated phenotypes.

\section{Acknowledgements}

Not applicable.

\section{Funding}

The present study was supported by the fund (grant no. 2018 to Chi-Jung Huang) from The Department of Medical Research of Cathay General Hospital.

\section{Availability of data and materials}

All data generated or analyzed during this study are included in this published article.

\section{Authors' contributions}

CSH, YCW and CYL designed the study. CSH and CYL wrote the initial version of the manuscript. JWG and $\mathrm{CCH}$ performed the cell studies. JWG, JYY and CYL performed the immunostaining and pathologic diagnosis. RNY, CLL, MHS and CCH interpreted the patient data regarding the well-differentiated and poorly-differentiated $\mathrm{CRC}$. $\mathrm{CCH}$ and $\mathrm{CJH}$ performed the statistical analyses. CYL provided supervision throughout the study. All authors discussed, modified and approved of the final version.

\section{Ethics approval and consent to participate}

All procedures were approved by The Cathay General Hospital Institutional Ethics Committee and a waiver of consent was approved by the same committee.

\section{Patient consent for publication}

Not applicable.

\section{Competing interests}

The authors declare that they have no competing interests.

\section{References}

1. Keighley MR: Gastrointestinal cancers in europe. Aliment Pharmacol Ther 18: 7-30, 2003.

2. Liu Y, Sethi NS, Hinoue T, Schneider BG, Cherniack AD, Sanchez-Vega F, Seoane JA, Farshidfar F, Bowlby R, Islam M, et al: Comparative molecular analysis of gastrointestinal adenocarcinomas. Cancer Cell 33: 721-735, 2018.

3. Vedeld HM, Andresen K, Eilertsen IA, Nesbakken A, Seruca R, Gladhaug IP, Thiis-Evensen E, Rognum TO, Boberg KM and Lind GE: The novel colorectal cancer biomarkers CDO1, ZSCAN18 and ZNF331 are frequently methylated across gastrointestinal cancers. Int J Cancer 136: 844-853, 2015.

4. Moll R, Levy R, Czernobilsky B, Hohlweg-Majert P, Dallenbach-Hellweg G and Franke WW: Cytokeratins of normal epithelia and some neoplasms of the female genital tract. Lab Invest 49: 599-610, 1983.

5. Kim HS, Lee JJ, Do SI, Kim K, Do IG, Kim DH, Chae SW and Sohn JH: Overexpression of cytokeratin 17 is associated with the development of papillary thyroid carcinoma and the presence of lymph node metastasis. Int J Clin Exp Pathol 8: 5695-5701, 2015.

6. Osborn M, van Lessen G, Weber K, Kloppel G and Altmannsberger M: Differential diagnosis of gastrointestinal carcinomas by using monoclonal antibodies specific for individual keratin polypeptides. Lab Invest 55: 497-504, 1986.

7. Tang KD, Kenny L, Perry C, Frazer I and Punyadeera C: The overexpression of salivary cytokeratins as potential diagnostic biomarkers in head and neck squamous cell carcinomas. Oncotarget 8: 72272-72280, 2017.

8. Tot T: Cytokeratins 20 and 7 as biomarkers: Usefulness in discriminating primary from metastatic adenocarcinoma. Eur J Cancer 38: 758-763, 2002.

9. Fuchs E: Keratins as biochemical markers of epithelial differentiation. Trends Genet 4: 277-281, 1988.

10. Lipkin M: Biomarkers of increased susceptibility to gastrointestinal cancer: New application to studies of cancer prevention in human subjects. Cancer Res 48: 235-245, 1988.

11. Mills JC and Sansom OJ: Reserve stem cells: Differentiated cells reprogram to fuel repair, metaplasia, and neoplasia in the adult gastrointestinal tract. Sci Signal 8: re 8, 2015.

12. Kalluri R and Weinberg RA: The basics of epithelial-mesenchymal transition. J Clin Invest 119: 1420-1428, 2009.

13. Chen T, You Y, Jiang H and Wang ZZ: Epithelial-mesenchymal transition (EMT): A biological process in the development, stem cell differentiation, and tumorigenesis. J Cell Physiol 232: 3261-3272, 2017.

14. Zou XZ, Liu T, Gong ZC, Hu CP and Zhang Z: MicroRNAs-Mediated epithelial-mesenchymal transition in fibrotic diseases. Eur J Pharmacol 796: 190-206, 2017.

15. Serrano MJ, Ortega FG, Alvarez-Cubero MJ, Nadal R, Sanchez-Rovira P, Salido M, Rodriguez M, Garcia-Puche JL, Delgado-Rodriguez M, Sole F, et al: EMT and EGFR in CTCs cytokeratin negative non-metastatic breast cancer. Oncotarget 5: 7486-7497, 2014 
16. Hinz S, Hendricks A, Wittig A, Schafmayer C, Tepel J, Kalthoff $\mathrm{H}$, Becker T and Roder C: Detection of circulating tumor cells with CK20 RT-PCR is an independent negative prognostic marker in colon cancer patients-a prospective study. BMC Cancer 17: 53, 2017.

17. Chang WL, Liu YW, Dang YL, Jiang XX, Xu H, Huang X, Wang YL, Wang H, Zhu C, Xue LQ, et al: PLAC8, a new marker for human interstitial extravillous trophoblast cells, promotes their invasion and migration. Development 145: dev148932, 2018.

18. Li C, Ma H, Wang Y, Cao Z, Graves-Deal R, Powell AE, Starchenko A, Ayers GD, Washington MK, Kamath V, et al: Excess PLAC8 promotes an unconventional ERK2-dependent EMT in colon cancer. J Clin Invest 124: 2172-2187, 2014

19. Miettinen M: Keratin 20: Immunohistochemical marker for gastrointestinal, urothelial, and merkel cell carcinomas. Mod Pathol 8: 384-388, 1995.

20. Moll R, Divo M and Langbein L: The human keratins: Biology and pathology. Histochem Cell Biol 129: 705-733, 2008

21. Rogulski K, Li Y, Rothermund K, Pu L, Watkins S, Yi F and Prochownik EV: Onzin, a c-Myc-repressed target, promotes survival and transformation by modulating the Akt-Mdm2-p53 pathway. Oncogene 24: 7524-7541, 2005.

22. Jia Y, Ying X, Zhou J, Chen Y, Luo X, Xie S, Wang QC, Hu W and Wang L: The novel KLF4/PLAC8 signaling pathway regulates lung cancer growth. Cell Death Dis 9: 603, 2018.

23. Amin MB, Greene FL, Edge SB, Compton CC, Gershenwald JE, Brookland RK, Meyer L, Gress DM, Byrd DR and Winchester DP: The eighth edition AJCC cancer staging manual: Continuing to build a bridge from a population-based to a more 'personalized' approach to cancer staging. CA Cancer J Clin 67: 93-99, 2017.

24. Lee CL, Huang CJ, Yang SH, Chang CC, Huang CC, Chien CC and Yang RN: Discovery of genes from feces correlated with colorectal cancer progression. Oncol Lett 12: 3378-3384, 2016.

25. Huang CJ, Lee CL, Yang SH, Chien CC, Huang CC, Yang RN and Chang CC: Upregulation of the growth arrest-specific-2 in recurrent colorectal cancers, and its susceptibility to chemotherapy in a model cell system. Biochim Biophys Acta 1862 $1345-1353,2016$

26. Livak KJ and Schmittgen TD: Analysis of relative gene expression data using real-time quantitative PCR and the 2(-Delta Delta C(T)) method. Methods 25: 402-408, 2001.

27. Washington MK, Berlin J, Branton P, Burgart LJ, Carter DK, Fitzgibbons PL, Halling K, Frankel W, Jessup J, Kakar S, et al: Protocol for the examination of specimens from patients with primary carcinoma of the colon and rectum. Arch Pathol Lab Med 133: 1539-1551, 2009.

28. Duffy MJ, Lamerz R, Haglund C, Nicolini A, Kalousova M, Holubec L and Sturgeon C: Tumor markers in colorectal cancer, gastric cancer and gastrointestinal stromal cancers: European group on tumor markers 2014 guidelines update. Int J Cancer 134 2513-2522, 2014

29. Dolscheid-Pommerich RC, Manekeller S, WalgenbachBrunagel G, Kalff JC, Hartmann G, Wagner BS and Holdenrieder S: Clinical performance of CEA, CA19-9, CA15-3, CA125 and AFP in gastrointestinal cancer using LOCI-based assays. Anticancer Res 37: 353-359, 2017.

30. Kumar Y, Tapuria N, Kirmani N and Davidson BR: Tumour M2-pyruvate kinase: A gastrointestinal cancer marker. Eu J Gastroenterol Hepatol 19: 265-276, 2007

31. Myllykangas S, Bohling T and Knuutila S: Specificity, selection and significance of gene amplifications in cancer. Semin Cancer Biol 17: 42-55, 2007 .

32. Myllykangas S, Himberg J, Bohling T, Nagy B, Hollmen J and Knuutila S: DNA copy number amplification profiling of human neoplasms. Oncogene 25: 7324-7332, 2006

33. Lukyanchuk VV, Friess H, Kleeff J, Osinsky SP, Ayuni E, Candinas D and Roggo A: Detection of circulating tumor cells by cytokeratin 20 and prostate stem cell antigen RT-PCR in blood of patients with gastrointestinal cancers. Anticancer Res 23: 2711-2716, 2003.

34. Dalerba P, Sahoo D, Paik S, Guo X, Yothers G, Song N, Wilcox-Fogel N, Forgo E, Rajendran PS, Miranda SP, et al: CDX2 as a prognostic biomarker in stage II and stage III colon cancer. N Engl J Med 374: 211-222, 2016.

35. Pilati C, Taieb J, Balogoun R, Marisa L, de Reynies A and Laurent-Puig P: CDX2 prognostic value in stage II/III resected colon cancer is related to CMS classification. Ann Oncol 28: $1032-1035,2017$
36. Singh R, Kapur N, Mir H, Singh N, Lillard JW Jr and Singh S: CXCR6-CXCL16 axis promotes prostate cancer by mediating cytoskeleton rearrangement via Ezrin activation and alphavbeta3 integrin clustering. Oncotarget 7: 7343-7353, 2016.

37. Wu K, Zhang X, Li F, Xiao D, Hou Y, Zhu S, Liu D, Ye X, Ye M, Yang $\mathrm{J}$, et al: Frequent alterations in cytoskeleton remodelling genes in primary and metastatic lung adenocarcinomas. Nat Commun 6: 10131, 2015

38. Chen NP, Uddin B, Voit R and Schiebel E: Human phosphatase $\mathrm{CDC14A}$ is recruited to the cell leading edge to regulate cell migration and adhesion. Proc Natl Acad Sci USA 113: 990-995, 2016.

39. Zhou H, Zhang Y, Chen Q and Lin Y: AKT and JNK signaling pathways increase the metastatic potential of colorectal cancer cells by altering transgelin expression. Dig Dis Sci 61: 1091-1097, 2016.

40. Mills KM, Brocardo MG and Henderson BR: APC binds the Miro/Milton motor complex to stimulate transport of mitochondria to the plasma membrane. Mol Biol Cell 27: 466-482, 2016.

41. Ivanovska J, Zlobec I, Forster S, Karamitopoulou E, Dawson H, Koelzer VH, Agaimy A, Garreis F, Soder S, Laqua W, et al: DAPK loss in colon cancer tumor buds: Implications for migration capacity of disseminating tumor cells. Oncotarget 6 : 36774-36788, 2015.

42. Zeng Y, Xie H, Qiao Y, Wang J, Zhu X, He G, Li Y, Ren X, Wang $F$, Liang $L$ and Ding Y: Formin-Like2 regulates Rho/ROCK pathway to promote actin assembly and cell invasion of colorectal cancer. Cancer Sci 106: 1385-1393, 2015.

43. Asfaha S, Hayakawa Y, Muley A, Stokes S, Graham TA, Ericksen RE, Westphalen CB, von Burstin J, Mastracci TL, Worthley DL, et al: Krt19(+)/Lgr5(-) cells are radioresistant cancer-initiating stem cells in the colon and intestine. Cell Stem Cell 16: 627-638, 2015.

44. Li WX, Xiao HW, Hong XQ and Niu WX: Predictive value of CK20 in evaluating the efficacy of treatment and prognosis after surgery for colorectal cancer. Genet Mol Res 14: 5823-5829, 2015.

45. Saad RS, Ismiil N, Dube V, Nofech-Mozes S and Khalifa MA CDX-2 expression is a common event in primary intestinal-type endocervical adenocarcinoma. Am J Clin Pathol 132: 531-538, 2009.

46. Bluemke K, Bilkenroth U, Meye A, Fuessel S, Lautenschlaeger C, Goebel S, Melchior A, Heynemann H, Fornara P and Taubert H: Detection of circulating tumor cells in peripheral blood of patients with renal cell carcinoma correlates with prognosis. Cancer Epidemiol Biomarkers Prev 18: 2190-2194, 2009.

47. Mizuuchi E, Semba S, Kodama Y and Yokozaki H: Down-modulation of keratin 8 phosphorylation levels by PRL-3 contributes to colorectal carcinoma progression. Int J Cancer 124: 1802-1810, 2009

48. Ding SJ, Li Y, Tan YX, Jiang MR, Tian B, Liu YK, Shao XX, Ye SL, Wu JR, Zeng R, et al: From proteomic analysis to clinical significance: Overexpression of cytokeratin 19 correlates with hepatocellular carcinoma metastasis. Mol Cell Proteomics 3: 73-81, 2004.

49. Hammoudi A, Song F, Reed KR, Jenkins RE, Meniel VS, Watson AJ, Pritchard DM, Clarke AR and Jenkins JR: Proteomic profiling of a mouse model of acute intestinal apc deletion leads to identification of potential novel biomarkers of human colorectal cancer (CRC). Biochem Biophys Res Commun 440: 364-370, 2013

50. Yang SH, Huang CJ, Lee CL, Liu CC, Chien CC and Chen SH: Fecal RNA detection of cytokeratin 19 and ribosomal protein L19 for colorectal cancer. Hepatogastroenterology 57: 710-715, 2010.

51. Yang RN, Yang SH, Chang CC, Chien CC, Pan S and Huang CJ: Upregulation of fecal cytokeratin 19 is associated with prognosis in older colorectal cancer patients. Genet Test Mol Biomarkers 14: 703-708, 2010.

52. Chang CC, Yang SH, Chien CC, Chen SH, Pan S, Lee CL, Lin CM, Sun HL, Huang CC, Wu YY, et al: Clinical meaning of age-related expression of fecal cytokeratin 19 in colorectal malignancy. BMC Cancer 9: 376, 2009.

53. Kende AI, Carr NJ and Sobin LH: Expression of cytokeratins 7 and 20 in carcinomas of the gastrointestinal tract. Histopathology 42: 137-140, 2003.

54. Samija I, Lukac J, Mubrin MK, Kirac I, Kovacevic D and Kusic Z: Detection of cytokeratin-20-positive cells in preoperative and postoperative blood samples from colorectal cancer patients by real-time RT-PCR. Int J Biol Markers 28: 174-181, 2013. 
55. Kojima S, Sakamoto T, Nagai Y, Honda M and Ogawa F: Metachronous rectal metastasis from primary transverse colon cancer: A case report. Surg Case Rep 4: 90, 2018.

56. Reisher SR, Hughes TE, Ordovas JM, Schaefer EJ and Feinstein SI: Increased expression of apolipoprotein genes accompanies differentiation in the intestinal cell line Caco-2. Proc Natl Acad Sci USA 90: 5757-5761, 1993.

57. Ferruzza S, Rossi C, Scarino ML and Sambuy Y: A protocol for differentiation of human intestinal Caco-2 cells in asymmetric serum-containing medium. Toxicol In Vitro 26: 1252-1255, 2012

58. Meunier V, Bourrie M, Berger Y and Fabre G: The human intestinal epithelial cell line Caco-2; pharmacological and pharmacokinetic applications. Cell Biol Toxicol 11: 187-194, 1995.

59. Buhrke T, Lengler I and Lampen A: Analysis of proteomic changes induced upon cellular differentiation of the human intestinal cell line Caco-2. Dev Growth Differ 53: 411-426, 2011.

60. Allegra C and Sargent D: Molecular diagnostics: Assays, tissues, progress, and pitfalls. J Clin Oncol 21: 395-396, 2003.

61. Bustin SA and Dorudi S: Gene expression profiling for molecular staging and prognosis prediction in colorectal cancer. Expert Rev Mol Diagn 4: 599-607, 2004.

62. Bardelli A and Velculescu VE: Mutational analysis of gene families in human cancer. Curr Opin Genet Dev 15: 5-12, 2005.

63. Rozen P: Cancer of the gastrointestinal tract: Early detection or early prevention? Eur J Cancer Prev 13: 71-75, 2004.

64. Vogelstein B, Fearon ER, Hamilton SR, Kern SE, Preisinger AC, Leppert M, Nakamura Y, White R, Smits AM and Bos JL: Genetic alterations during colorectal-tumor development. N Engl J Med 319: 525-532, 1988.

65. Center MM, Jemal A, Smith RA and Ward E: Worldwide variations in colorectal cancer. CA Cancer J Clin 59: 366-378, 2009.

66. Le DT, Uram JN, Wang H, Bartlett BR, Kemberling H, Eyring AD, Skora AD, Luber BS, Azad NS, Laheru D, et al: PD-1 blockade in tumors with mismatch-repair deficiency. N Engl J Med 372: 2509-2520, 2015.

67. Cunningham D, Humblet Y, Siena S, Khayat D, Bleiberg H Santoro A, Bets D, Mueser M, Harstrick A, Verslype C, et al: Cetuximab monotherapy and cetuximab plus irinotecan in irinotecan-refractory metastatic colorectal cancer. N Engl J Med 351: 337-345, 2004.
68. Hurwitz H, Fehrenbacher L, Novotny W, Cartwright T, Hainsworth J, Heim W, Berlin J, Baron A, Griffing S, Holmgren E, et al: Bevacizumab plus irinotecan, fluorouracil, and leucovorin for metastatic colorectal cancer. N Engl J Med 350: 2335-2342, 2004.

69. Imai Y, Yamagishi H, Fukuda K, Okamura T, Ono Y, Ban S, Inoue T and Ueda Y: Expression of cytokeratin 20 indicates invasive histological phenotype in poorly differentiated colorectal adenocarcinoma. Anticancer Res 34: 159-167, 2014.

70. Barr T, Sureshchandra S, Ruegger P, Zhang J, Ma W, Borneman J, Grant $\mathrm{K}$ and Messaoudi I: Concurrent gut transcriptome and microbiota profiling following chronic ethanol consumption in nonhuman primates. Gut Microbes 9: 338-356, 2018.

71. Turroni S, Vitali B, Candela M, Gionchetti P, Rizzello F, Campieri $M$ and Brigidi P: Antibiotics and probiotics in chronic pouchitis: A comparative proteomic approach. World J Gastroenterol 16: 30-41, 2010.

72. Singh A, Trivedi P and Jain NK: Advances in siRNA delivery in cancer therapy. Artif Cells Nanomed Biotechnol 46: 274-283, 2018.

73. Das M, Musetti S and Huang L: RNA interference-based cancer drugs: The roadblocks, and the 'Delivery' of the promise. Nucleic Acid Ther 29: 61-66, 2019.

74. Zheng M, Tao W, Zou Y, Farokhzad OC and Shi B: Nanotechnology-based strategies for siRNA brain delivery for disease therapy. Trends Biotechnol 36: 562-575, 2018.

75. Bukholm IR, Bondi J, Wiik P, Nesland JM, Andersen SN, Bakka A and Bukholm G: Presence of isolated tumour cells in mesenteric lymph nodes predicts poor prognosis in patients with stage II colon cancer. Eur J Surg Oncol 29: 862-866, 2003.

76. Zhang Y, Hu Q, Li G, Li L, Liang S, Zhang Y, Liu J, Fan Z, Li L, Zhou B, et al: ONZIN upregulation by mutant $\mathrm{p} 53$ contributes to osteosarcoma metastasis through the CXCL5-MAPK signaling pathway. Cell Physiol Biochem 48: 1099-1111, 2018.

(7) $\Theta$ This work is licensed under a Creative Commons Attribution-NonCommercial-NoDerivatives 4.0 International (CC BY-NC-ND 4.0) License. 